\title{
SEPARATION OF HUMAN SERUM COMPONENTS CAPABLE OF INDUCING THE ACROSOME REACTION IN HAMSTER SPERMATOZOA
}

\author{
B. D. BAVISTER* AND D. B. MORTON \\ Physiological Laboratory, Downing Street, Cambridge CB2 3 EG, and \\ Strangeways Research Laboratory, Wort's Causeway, Cambridge CB1 $4 R \mathcal{N}$
}

(Received 30th April 1974)

A fraction that stimulates hamster sperm motility can be obtained from human serum by Sephadex gel filtration (Morton \& Bavister, 1974). The proteinrich fractions potentiate this activity and effectively induce the acrosome reaction. Here, we describe attempts to determine the type of protein that may be involved.

The methods used to prepare the motility-stimulating fraction from human serum and for assessing its activity were as previously described (Morton \& Bavister, 1974). To help identify which serum component induced the acrosome reaction, serum proteins were chromatographically separated on Sephadex G-150 (5 ml pooled human serum fractionated on $130 \mathrm{ml}$ bed volume G-150 in a $1.5 \times 90 \mathrm{~cm}$ column, fraction size $1.6 \mathrm{ml}$, flow rate $10 \mathrm{ml} / \mathrm{hr}$ ). Protein was monitored by absorption at $280 \mathrm{~nm}$ with an LKB Uvicord II (see Text-fig. 1). The G-150 column was calibrated with Blue Dextran, human IgG, bovine serum albumin, chymotrypsinogen, cytochrome $c$ and potassium ferricyanide. An aliquot of every third fraction over the protein peaks was mixed with an equal volume of the motility-stimulating fraction; $50-\mu 1$ drops were equilibrated under paraffin oil with $5 \% \mathrm{CO}_{2}$ in air at $37^{\circ} \mathrm{C}$, and hamster epididymal spermatozoa were added (final sperm concentration of $1 \times 10^{6} / \mathrm{ml}$ ). After incubation for $6 \mathrm{hr}$, the motility-stimulating activity was considerably enhanced by G-150 Fractions 41 to 50 (Text-fig. la) and the percentage of motile spermatozoa showing the acrosome reaction after incubation for $5 \frac{1}{2} \mathrm{hr}$ (Text-fig. lb) also increased sharply from Fraction 41 (30 to $40 \%$ of the spermatozoa were still motile at this time). These results indicate that serum proteins with an approximate molecular weight of between 80,000 and 180,000 are most effective at inducing the acrosome reaction in conjunction with the motility-stimulating fraction of serum.

Potentiation of motility-stimulating activity was also tested with several commercial protein preparations, i.e. crystalline and Cohn Fraction V bovine serum albumin, Cohn Fraction V fatty acid-free human serum albumin, and crystalline chicken ovalbumin. A $2 \%$ solution of each protein was made in Tyrode-Dextran (Morton \& Bavister, 1974). Bovine serum $\alpha$-globulin (Cohn

* Present address: Department of Anatomy, University of Hawaii Medical School, 1960 East West Road, Honolulu, Hawaii 96822, U.S.A. 
Fraction IV) and $\beta$-globulin (Cohn Fraction III) were also tested but their solubility was low and the solutions used contained less than $2 \%$ protein. After adjusting the $\mathrm{pH}$ to $7 \cdot 6$, each of these solutions was mixed with an equal volume of the motility-stimulating fraction and tested (Text-fig. 2). The
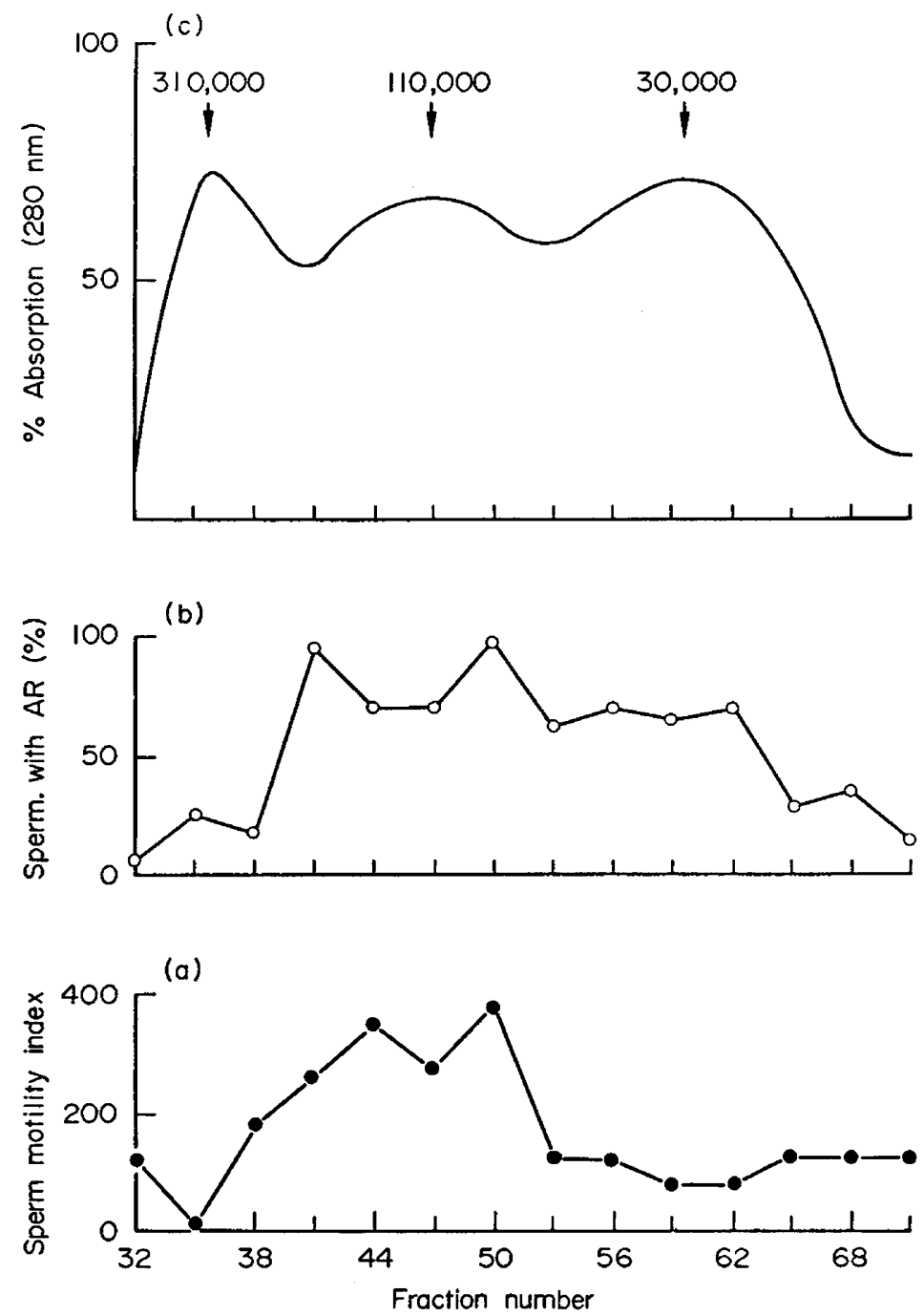

TEXT-FIG. 1. The effect of human serum components on hamster spermatozoa. G-150 serum fractions mixed 1:1 with sperm motility-stimulating fraction. (a) Sperm motility index after incubation for $6 \mathrm{hr}$; (b) percentage of motile spermatozoa showing acrosome reaction (AR) after incubation for $5 \frac{1}{2} \mathrm{hr}$; (c) LKB Uvicord trace of G-150 fractionation. Molecular weights deduced from a calibration run are arrowed.

motility-stimulating activity was enhanced to various degrees by all the preparations except the $\beta$-globulin, which was lethal to hamster spermatozoa. After incubation for $5 \frac{1}{2} \mathrm{hr}$, however, only the two Fraction $\mathrm{V}$ albumin preparations had induced a high proportion of living spermatozoa to undergo the acrosome reaction. 
Table 1. The interaction of the 'motility-stimulating fraction' of human serum with proteins: effects on the fertilization of hamster eggs in vitro

\begin{tabular}{|c|c|c|c|c|c|c|}
\hline & \multicolumn{5}{|c|}{ Motility-stimulating fraction mixed $1: 1$ with: } & \multirow{2}{*}{$\begin{array}{c}G-150 \\
\text { Fraction } \\
50+\text { culture } \\
\text { medium }\end{array}$} \\
\hline & $\begin{array}{l}\text { Culture } \\
\text { medium }\end{array}$ & $\begin{array}{c}G 150 \\
\text { Fraction } \\
50\end{array}$ & $\begin{array}{l}\text { Human } \\
\text { serum } \\
\text { albumin }\end{array}$ & Ovalbumin & $\alpha$-Globulin & \\
\hline Total no. of eggs & 29 & 30 & 26 & 28 & 24 & 29 \\
\hline Fertilized eggs & 0 & 18 & 23 & 6 & 22 & 0 \\
\hline $\begin{array}{l}\text { Spermatozoa in the } \\
\text { perivitelline space only }\end{array}$ & $\mathbf{0}$ & 5 & 3 & 6 & 1 & 0 \\
\hline $\begin{array}{l}\text { Degree of sperm attachment } \\
\text { to zona pellucida }\end{array}$ & + & ++ & +++ & + & & 0 \\
\hline
\end{tabular}

Results given are totals of two experiments. All eggs were freed from cumulus and washed thoroughly. Sperm attachment was estimated on scale of $0,+$ (light) to +++ (heavy).

In a preliminary study, we tested the contribution of the motility-stimulating fraction, alone or in combination with protein, to the fertilization of hamster eggs in vitro. Hamsters were treated with 25 i.u. PMSG followed 48 to $54 \mathrm{hr}$ later by 25 i.u. HCG and superovulated eggs were recovered from their oviducts I5 to $17 \mathrm{hr}$ after giving the HCG. Five or six cumulus masses were pooled and the cumulus cells were detached by incubation for $15 \mathrm{~min}$ in Tyrode-Dextran medium containing 75 N.F. units hyaluronidase/ml. The naked eggs were subsequently rinsed thoroughly in $3 \mathrm{ml} \mathrm{PBl}$ medium, without bovine serum albumin (Whittingham, 1971). Aliquots of motility-stimulating fraction

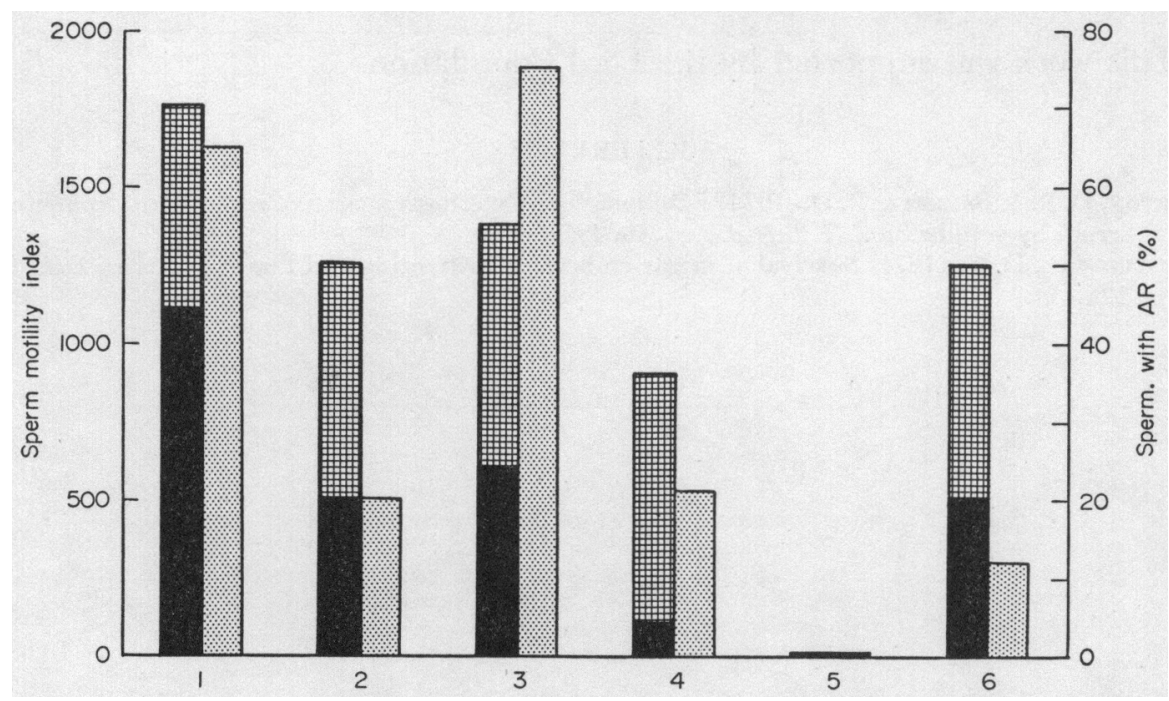

TEXT-FIG. 2. Histogram showing the effects of various proteins on the sperm motility index after incubation for $2 \frac{1}{2} \mathrm{hr}$ (solid columns) and $4 \frac{1}{2} \mathrm{hr}$ (hatched columns) with motility-stimulating fraction, and on the percentage acrosome reaction (AR) (stippled columns) after incubation for $5 \mathrm{hr} .1$, Bovine serum albumin (Fraction V);2, bovine serum albumin (crystallized); 3 , human serum albumin (Fraction V, fatty acid free); 4 , bovine $\alpha$-globulin; 5 , bovine $\beta$-globulin; 6 , chicken ovalbumin. 
were mixed with an equal volume of Tyrode-Dextran alone or containing various proteins (Table 1). The G-150 column Fraction 50, which had the greatest motility-enhancing effect (see Text-fig. la), was also tested. The test drops were equilibrated with $5 \% \mathrm{CO}_{2}$ in air under paraffin oil and eggs were allocated to the drops; in each of two experiments, one batch of washed eggs was distributed among all treatments. A freshly prepared epididymal sperm suspension was added to the drops (to make a final sperm concentration of approximately $1 \times 10^{6} / \mathrm{ml}$ ) which were then incubated at $37^{\circ} \mathrm{C}$ overnight. Eggs were examined for evidence of fertilization (two polar bodies, two pronuclei, and at least one sperm tail in the vitellus). Neither the G-150 protein fraction, nor the motility-stimulating fraction alone, was capable of replacing the essential cumulus components removed by hyaluronidase digestion and washing (Table 1). Fertilization was accomplished, however, when the motility-stimulating fraction was combined with different protein preparations, including the G-150 Fraction 50 . Sperm attachment to the zona pellucida was noticeably dependent on the type of protein used.

These preliminary results demonstrate that components of human serum can stimulate capacitation and the acrosome reaction of hamster spermatozoa, and can be separated by gel filtration. The active fractions could replace the sperm motility-stimulating and acrosome reaction-inducing components normally involved in fertilization of hamster eggs. Preparations of proteins from different sources were effective to various degrees in replacing the human serum-derived protein component; further examination and purification of the serum components should assist in the identification of the agents involved, and clarify their rôles in capacitation, the acrosome reaction and fertilization.

This work was supported by the Ford Foundation.

\section{REFERENCES}

Morton, D. B. \& Bavister, B. D. (1974) Fractionation of sperm-capacitating components from human serum by gel filtration. $\mathcal{F}$. Reprod. Fert. 40, 491.

Whittingham, D. G. (1971) Survival of mouse embryos after freezing and thawing. Nature, Lond. 233, 125. 